文

\title{
瞬時色恒常性におよぼす周辺刺激と色の見えの判断基準の効果
}

\author{
非会員 栗 木 - 郎 (東京工業大学) 正会員 内 川 惠 二（東京工業大学）
}

\section{The Effects of Surround Stimulus and Color Matching Criterion on Simultaneous Color Con- stancy}

Ichiro Kuriki(Non-member) and Keiji Uchikawa(Member)

Tokyo Institute of Technology, Imaging Science and Engineering Laboratory

\begin{abstract}
We made a series of asymmetric color matching experiments between an actual color chip under different illuminant and a CRT simulated color chip, by changing surround, illuminant and matching criteria. The observers were asked to match hue, saturation and luminance of two stimuli at apparent-color match criteria, and were asked to match as if the two stimuli were made of the same surface at surface-color match criteria. At the condition without adaptation, and without any surround, the observer was not able to make surface-color match and the results for apparent-color match were the same with the physical chromaticity of the stimulus. At the same time, the condition with gray surround, we could find a shift in color appearance toward color constancy in both criteria, and at the condition with mondrian surround, the degree of color constancy for apparent-color match were improved by the increase of surround color information. However, at the condition without adaptation, the results for apparent-color match were less complete than the results for surface-color match, in terms of the degree of color constancy. At the condition with 15 minutes of adaptation to the illuminant, the results for apparent-color match achieved almost the same degree of color constancy with the results for surface-color match. Our results imply that the perfect color constancy will be achieved not only by surround stimulus, but also by the adaptation to the illuminant.
\end{abstract}

KEYWORDS: color constancy, apparent color, surface color, surround, adaptation, mode of color appearance

\section{1.はじめに}

色恒常性は日常生活の中でごく自然に生じているものである が，そのメカニズムは複雑であり，末だ解明されていない点が多 い. 物体表面の色は，まず照明光が物体表面に入射し，次にその 反射光が視覚系の光受容器に感受され, さらに視覚系内で光受容 器の応答が情報処理された結果である。ここで, 照明光のスペク トルが変化したと仮定すると, 物体表面で反射された光のスペク トルも当然変化し, 結果として被験者の視覚系の光受容器の応答 に変化を引き起こす．また，同様な反射光の変化は照明光のスぺ クトルが変化しなくても, 物体表面の分光反射率が変化しても生 じる、したがって, 被験者は反射光の変化が生じたのが照明光の 変化によるものか, 反射表面の変化によるものかは分からない. しかしながら, 視覚系がその光受容器の応答の変化のみから, そ の変化が照明光によるものか, 物体表面の変化によるものかが分 かり, 照明光が変化した場合には, 物体の表面の色は変化してい ないと知覚する，たとえば，白い紙はどのような照明光の下でも “白い”と知覚するという現象である。このような現象を色恒常 性と言う2).

本研究の一部は平成 5 年度照明学会全国大会において発表された。
異なるスペクトルから同じ物体表面色を知覚する現象は照明光 が変化するときにだけ生じるのではなく, 物体表面と照明光のな す位置関係が変化することによって物体表面の分光反射率が変化 した時にも得られる。一様に塗られた立体に一方向から光が射す 時に，ある面の色の変化を㓌影 (shading) として知覚するが，一 方，物体表面は一様に同じ色に塗られているという知覚をも得て いる。これも色恒常性の一つの形であると見ることができる3).

近年盛んになっている色恒常性の研究において，前者の照明光 変化に対して一定した色知覚を得る問題が主に取り上げられてい る.この問題に対しては Landの retinex 理論4)はじめ, 様々な アルゴリズムが提唱されているが, どれも決定的なものではない. その中でこれまでに大きく二つの代表的メカニズムが提唱されて いる。一つは色順応 ${ }^{516)}$, 一つは同時対比である ${ }^{788)}$. 色順応は現実 的な場面に対応して考えられたメカニズムであるが，瞬時に起こ る色恒常性を説明することができない，同時対比によるメカニズ 么は瞬時的な現象を説明できる一方，色恒常性では単純な色対比 以上の色シフトが起こっているという矛盾点を持っている。これ らの 2 つの中で特に同時対比に関連が梁い“瞬時的な色恒常性” という現象がそもそもあるのか，という問題提起もなされてい る ${ }^{11}$. しかし,これらの過去の研究では色恒常性がそもそもどの程 度成立するか1)といった問題に対して詳しく調べたものは少な 
く, 色恒常性の特性の記述もまだ不十分な点が多く残されている. 本研究では，瞬時的な色恒常性において，様々な周辺刺激を用 いた時に，照明光の変化を打ち消すような色恒常性の成立の度合 いがどのように変化してゆくのか，さらに，色の見えを評価する 判断基準を見えそのものの色(apparent color) と表面としての色 (surface color)としたときに違いがあるのかを調べた。さらに， 完全な照明光への順応があるときにおいても実験を行ない，結果 を比較した。

\section{2. 実験方法}

\section{1 実験装置および刺激}

実験装置の概略は図1の通りである.装置は大きく分けて左側の テスト刺激呈示部と右側の参照刺激呈示部からなっている.テス ト刺激としては OSA の均等色尺度を構成する色票 $(5 \mathrm{cmx} 5 \mathrm{~cm})$ を用い，参照刺激としては CRT にテスト刺激と同じ大きさの困 形をシミュレートした物を用いた。被験者はアゴ台にあごをのせ, 観察距離は両刺激とも $1.4 \mathrm{~m}$ である。被験者は手元にあるトラッ クボールで参照刺激の色度と輝度を変化させてマッチングを行な う.被験者と刺激との間にはタイマー制御のシャッターを設置し, 順応時, 非順応時ともに両方の刺激を同時に観察することによる 相互作用を除去した. シャッター開閉の時間設定は, 非順応条件, 順応条件で異なり，これについては後述する。

色票によるテスト刺激 $\left(2.2^{\circ} \times 2.2^{\circ}\right)$ は色温度変換フィル夕ーを 通した2台のスライドプロジェクターによってスポット照明され る。照明光として, 相関色温度および CIE $(1931)$ xy 色度が下記の 6種類を用いた；約 $1,000 \mathrm{~K}((\mathrm{x}, \mathrm{y})=):(0.661,0.340), 1,700 \mathrm{~K}$ : $(0.558,0.404), 2,400 \mathrm{~K}:(0.484,0.415), 3,400 \mathrm{~K}$ : $(0.412,0.415), 6,000 \mathrm{~K}:(0.323,0.380), 30,000 \mathrm{~K}$ : $(0.254,0.265)$. 照明光の照度はN 5 のマンセル色票をテスト刺激 の位置に呈示した際に約 $20 \mathrm{~cd} \mathrm{~m} \mathrm{~m}^{2}$ になるように調整してある. スポ ット照明光も，テスト刺激のわきから漏れた光も被験者から直接 見えないように遮蔽がなされている。

図2に示すとおり周辺刺激条件は 3 種類あり，（a）周辺刺激なし，

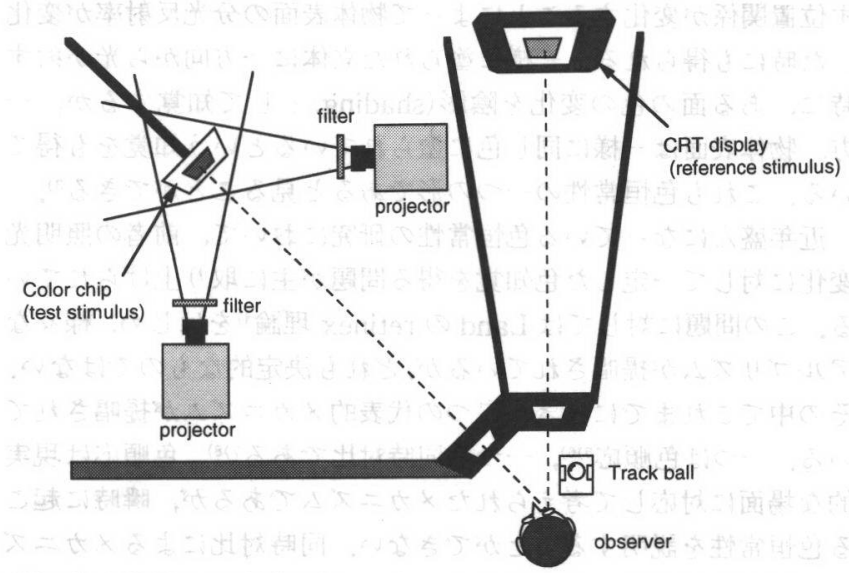

\section{図 1 実験装置概略}

被験者から見て左側が色票をスポットライトで照明したテスト刺激, 右側が CRTによってテスト刺激の D65照明時を模擬した参照刺激。テスト刺激と参 照刺激の周辺条件は常に同じ. 被験者は手元のトラックボールを操作してマッ チングを行なう.非順応時の実験では右眼単眼で視野を切り替える. 順応時の 実験では両眼隔壁がおかれ，被験者は左眼でテスト刺激，右眼で参照刺激を観 察する。どの順応条件でもタイマー制御シャッターを通して刺激を観察する。

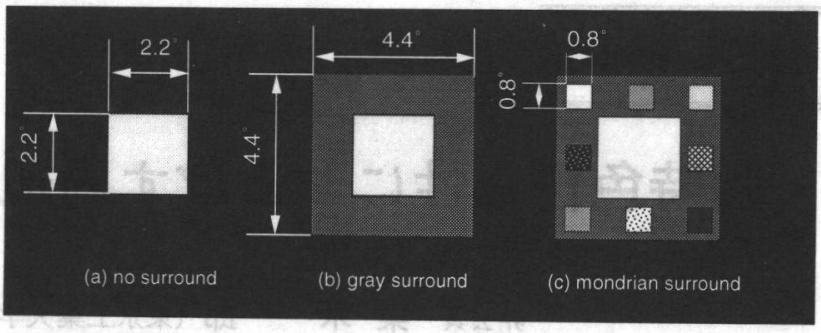

図 2 刺激

(a) 周辺刺激なし, (b) 灰色周辺刺激, (b)モンドリアン周辺刺激の3条件を示し ている.モンドリアン周辺刺激に用いた色票は, 5R4 12,5YR5 10,5Y8 10,5G5 8,5RP5 10,5PB5 10,10B5 10,5P5 10である.テスト刺激以外の周囲は暗黒で ある.

(b)灰色周辺刺激，（c）モンドリアン周辺刺激である。灰色周辺刺 激 $\left(4.4^{\circ} \times 4.4^{\circ}\right)$ はマンセル N 5色票によって作られており，モンド リアン周辺刺激 $\left(4.4^{\circ} \mathrm{x} 4.4^{\circ}\right)$ はマンセル N 5色票の上に8枚の色の 異なる色票 $\left(0.8^{\circ} \mathrm{x} 0.8^{\circ}\right)$ をのせて作られている。CRTによる参照 刺激は, テスト刺激 (テスト色票+周辺刺激)を $\mathrm{D}_{65}$ 照明光で照ら した時の反射光の色度点をシミュレートした物であり，被験者は 様々な照明光の下でのテスト刺激の見えを $\mathrm{D}_{65}$ 照明光の下でのテ スト刺激の見えとして再現することになる。

\section{2 実験手続}

非順応実験では被験者は右眼単眼で刺激を観察し，シャッター はテスト刺激側で4秒間，参照刺激側で6秒間交互に開閉する．被 験者はシャッターが開くのにあわせて交互に視野を換えて刺激を 観察しながら参照刺激の見えをテスト刺激の見えにマッチングす る.1試行が終わる毎に色票と照明光のフィルターを交換するため に両方のシャッターが閉じられ，被験者ブース内にある $\mathrm{D}_{65}$ 巣光 燈が点灯される. 被験者は $\mathrm{D}_{65}$ 蛍光燈を点灯した被験者ブースに 試行開始前に2分間入り, 照明光に順応する.テスト色票は灰色を 含む8枚で, 色票ごとに 6 種類の照明条件，3種類の周辺条件を 1 試 行ずつランダムな順序で呈示し，1セッションとした(合計144試 行).各被験者は 2 種類の判断基準ごとに5セッションの実験を行な った。

順応実験では被験者は顔前におかれた隔壁により，左眼でテス 卜刺激を, 右眼で参照刺激を観察する. 被験者はセッション開始 前に, 左眼でテスト刺激の前面にマンセル N 5 色票を呈示した順 応刺激 $\left(7^{\circ} \times 10^{\circ}\right.$, 約 $15 \mathrm{~cd} \mathrm{~m} \mathrm{~m}^{2}$ 観察し, 右眼では CRT の $\mathrm{D}_{65}$ 白色 $\left(7^{\circ}\right.$ $\left.\mathrm{x} 10^{\circ}, 15 \mathrm{~cd} \mathrm{~m}^{2}\right)$ を15分間観察することによって照明光への順応を 行なう。マッチング時は両刺激を同時に観察することによる弊害 を防ぐため,両刺激ともに 5 秒間ずつ交互に開閉するシャッターを 通して観察される. 順応条件の実験は, 色恒常性が成立しやすい 条件のモンドリアン周辺刺激のみで行った. 非順応条件と異なり, 順応時には1セッションを通して照明光は固定され, 試行間には両 方のシャッターが開放されて順応刺激を呈示することにより，左 右眼の順応状態を維持するように考慮した。

\section{3 判断基準}

照明光が変化したときに, 表面そのものの色が変わったのでは ないと感じながらも, 表面の見えの色は変化している. 実際, 室 内の照明光の下で見たときと, 屋外の太陽光の下で見たときとで 同じ表面の色の見えが微妙に異なる事はよく経験することであ る.しかし，一方では表面が変化したことは認識しないことも事 
実であり, 見えの色の知覚と, 表面そのものの色の知覚とは区別 されるべきものである。本論文では物体表面の属性としての色知 覚, すなわち表面色知覚を surface color と呼び，その知覚をあわ せることを surface-color match と呼ぶことにする。また，見え そのものの色の知覚を apparent color と呼び，その知覚をあわせ ることを apparentーcolor match と呼ぶ. 各判断基準に対する被 験者へのインストラクションは下記のとおうである.

apparent-color match:両方の刺激をそのままの状態で隣り合わ せにおいたときに，全く同じになるように色をあわせる，周辺に 刺激が呈示されている場合には周辺を無視して中央の色だけを完 全に合わせるようにする.

surface-color match:両方の刺激は共に同じ紙を異なる照明で照 らしたものである．両方の刺激をどちらか一方の照明の下に持っ ていって同時に観察した時に，全く同じ紙で構成されたものにな るように合わせる.

本研究では全ての実験条件においてこの2種類の判断基準にも とづくカラーマッチングを行ったが, 周辺刺激なしでは表面色知 覚を得ることはできなかったため, surface-color match を行な えなかった。実験ではセッション内の判断基準は一定である.

\section{4 被験者}

被験者 IK (25), TS (23), KU (42) は非順応条件, 順応条件の両 方を行った。 3 名とも色覚正常の男性である.被験者 RA (21), DM (22) はともにナイ一ブな被験者で色覚正常な男性であり，それぞ れ, 非順応条件, 順応条件のみの実験を行った。

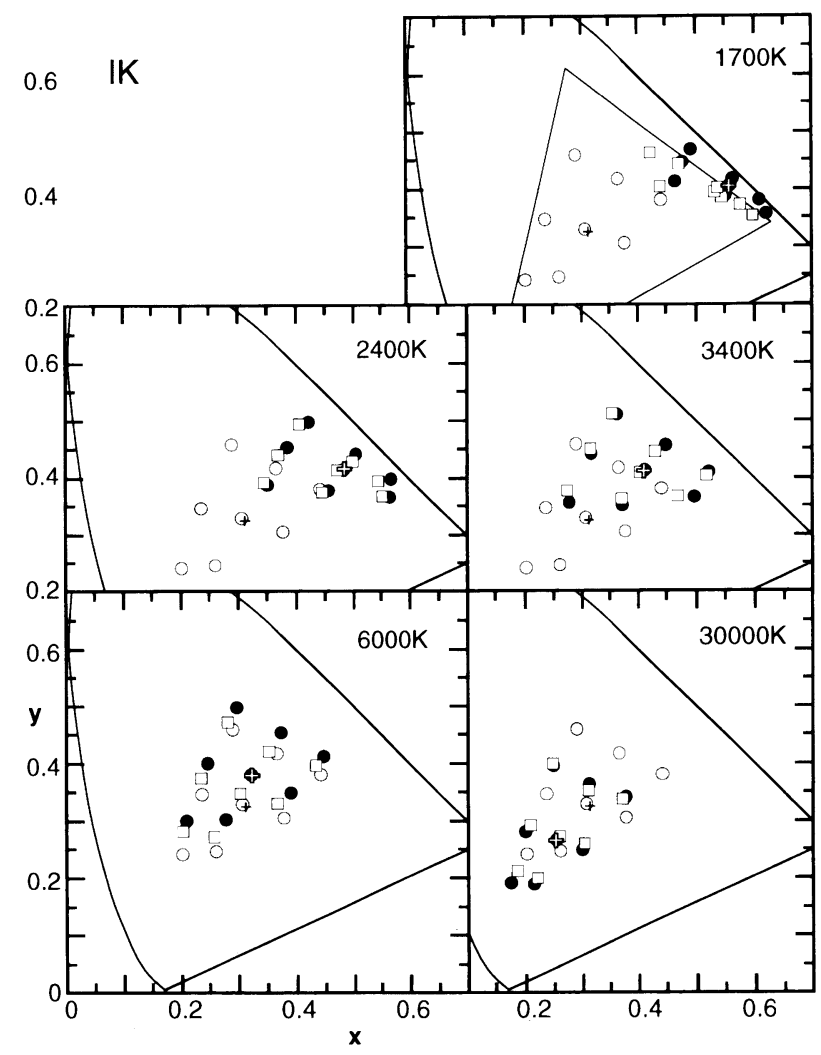

図 3 非順応時, 周辺刺激なしの被験者 IK の結果

○シンボルはテスト刺激の色度点, ○シンボルは完全な色恒常性成立時の色度 点を表している。ロシンボルは apparent - color matchの結果を表しており全 ての照明条件に沶いてテスト刺激の色度点とほぼ完全に一致している。他の被 呀者に関してもほほ同様の結果を得た。1,700Kにおける色度図内の線分は実 験に用いたCRTの色再現範讲を表寸三角形である。

\section{3. 実験結果}

\section{1 非順応条件}

非順応時の実験結果を CIE (1931) xy 色度図にプロットし, 図3, 4,5 に示す. ○シンボルは $\mathrm{D}_{65}$ 照明光の下でのテスト色票の色度点 を表し，マッチング結果が完全に色恒常性を保つとすると，この シンボルと重なることになる。・シンボルはパネルの右上に記さ れた各照明光の下でのテスト色票の色度点を表している。このシ ンボルにマッチング結果が一致すると，色恒常性が全く成立せず， 見えがテスト刺激の測色值と同じだけ変化していることを表す.

○，○シンボルに関しては困3６について共通である。田，田は それぞれ apparent-color match, surface-color match の結果 を表している。これらについては順次, 周辺刺激別に説明してい く、なお，全体に被験者間の傾向の差があまり見られなかったた め，モンドリアン周辺刺激の結果を除き，一人の被験者の結果で 代表して示す。

\section{1 .1 周辺刺激なし}

図3に周辺刺激なしの条件での被験者 IK のマッチング結果を ロシンボルで表す.この条件では surface-- color match を行なう ことができなかったため, apparent-color matchの結果のみを 示寸。全ての照明光においてほぼテスト刺激の測色点 ○シンボ ル）と一致し, 照明光の変化に対して色恒常性が全く成立しないこ とがわかる、1,700Kにおいて一部完全に一致していないのはテ ス卜刺激の色度点がCRTの色再現範囲を越えているためであ

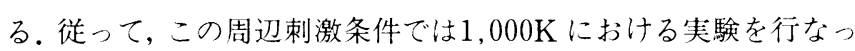

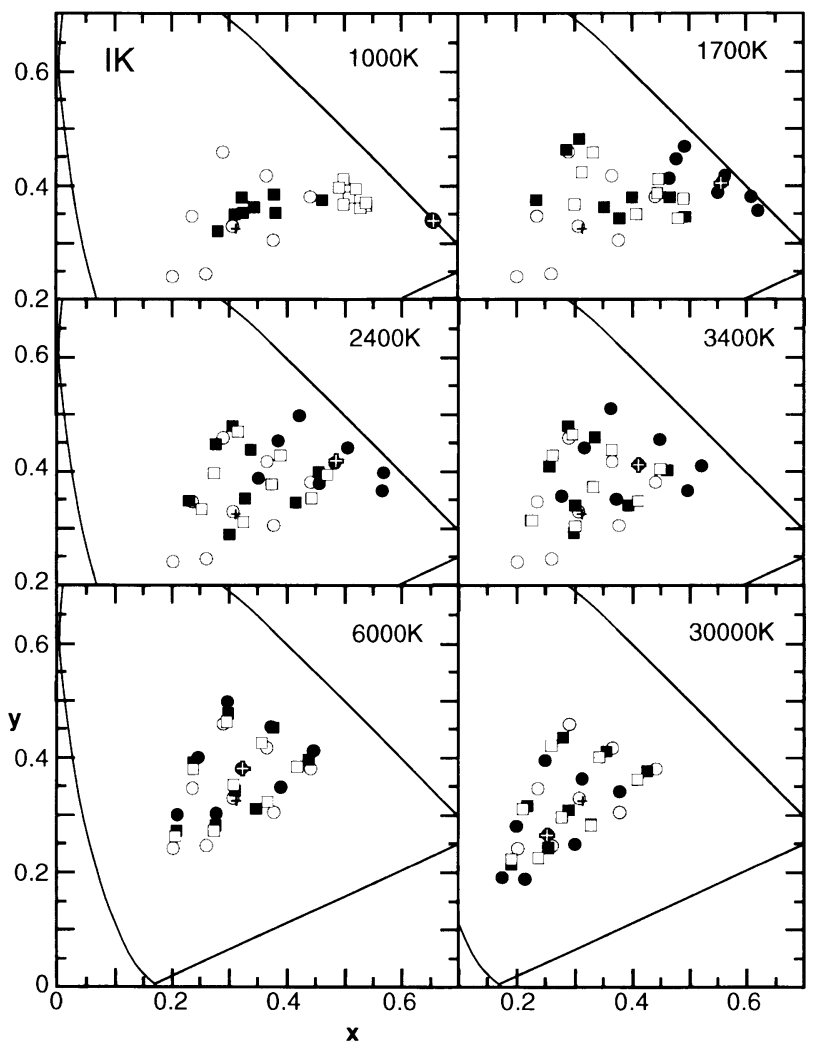

図 4 非順応時, 灰色周辺刺激の被験者 IK の結果

○シンボルについては四3に同じ.ロロシンボルは apparent-color match, ロシンボルは surface color - matchの結果を表している。ロシンボルは四3と 同じ判断基準であるが大幅に○シンボルの方向にシフトしている、ロシンボル は○シンボルに近く, 高い色恒常性が成立していることが分かるが, 完全な色 恒常性からのシフトも残っている。 

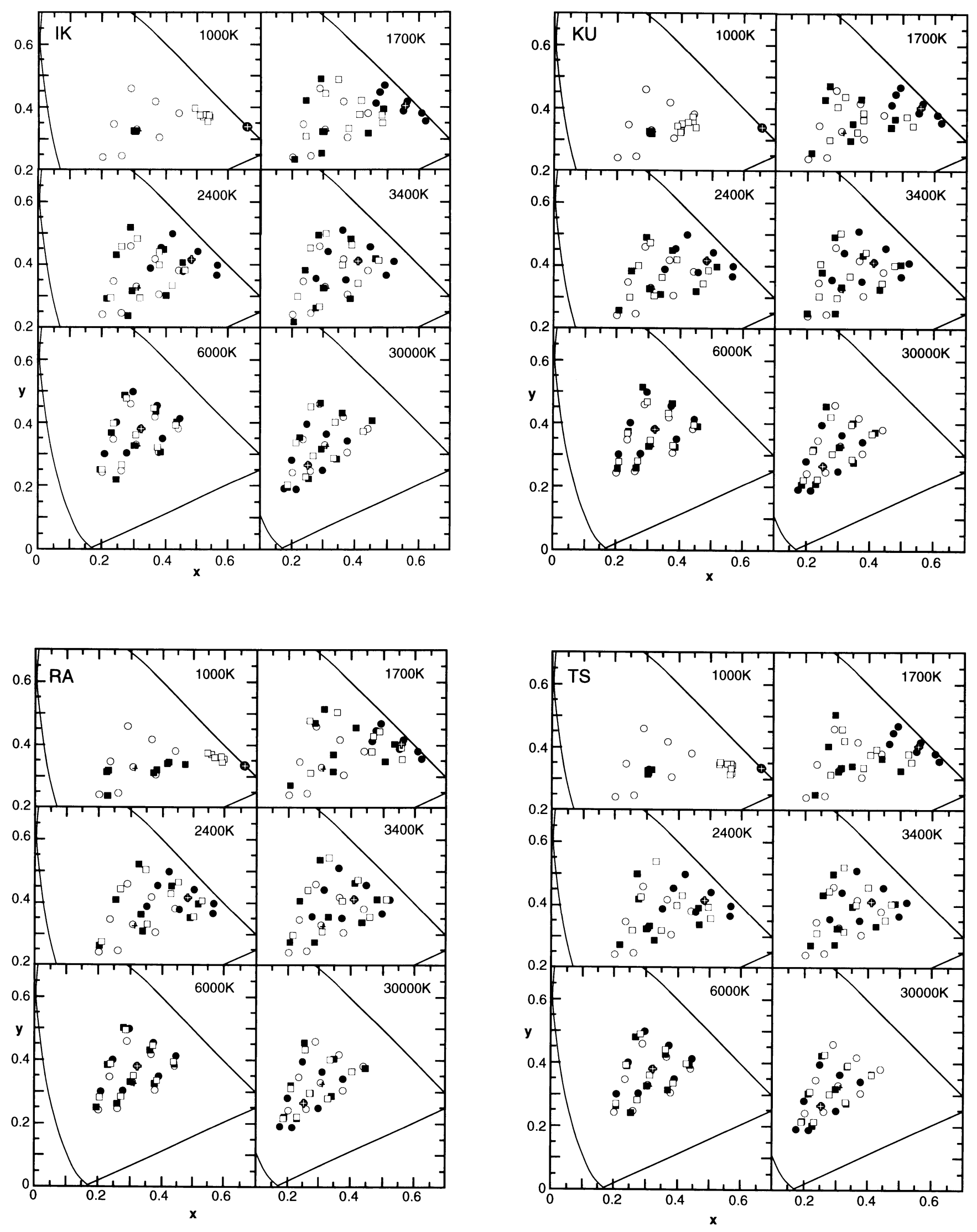

図 5 非順応時, モンドリアン周辺刺激の結果

シンボルは四4に同じ。ここでは全被験者の結果を示す。パネルの違いは被験者の違いを表している。ロシンボルが図4と比べてさらに○に近づいたことが分かるが, まだロシンボルの方が高い色恒常性を示している。 
ていない。

\section{1 .2 灰色周辺刺激}

四4に灰色周辺刺激における被験者 IK の結果を示す。ロシンボ ルは apparent-color match を表しており，この結果は周辺刺激 なしの条件(図3)と同じ判断基準で行なわれたマッチングである にもかかわらず，灰色の周辺刺激がついただけで色恒常性成立方 向への色シフトが起こっていることを表している. surfacecolor matchの結果はロシンボルで表されている. apparentcolor match に比べると色恒常性は若干高いが, 依然完全な色恒 常性(○シンボル)からの偏差は大きく, 表面色の知覚レベルでも 色恒常性が不完全であることを示している.

この灰色周辺刺激の $1,000 \mathrm{~K}$ の照明光の条件では surfacecolor matchの結果が $\mathrm{D}_{65}$ 照明下の無彩色色票の色度点付近に分 布し, 被験者によっては完全に無彩色色票の色度点に一致してい る。これは, 被験者の表面色知覚が無彩色になって完全に色恒常 性が失われているという興味深い結果を示している. apparent一 color match は測色点と surface-color matchを結んだ線上の ほぼ中間にあり，テスト刺激の見えが測色点よりも低彩度になっ ていることがわかる，1,000Kでは周辺刺激をふくめ全てのテス 卜刺激の測色点は完全にスペクトル軌跡にのっているため, 完全 に見えそのもののマッチングが行なわれていれば，図3の $1,700 \mathrm{~K}$ の条件のように CRT 色再現範囲の限界近くでマッチするはずで ある。しかし，得られた結果がそれよりも低彩度であるのは，マ ッチング用の参照刺激には $\mathrm{D}_{65}$ 照明下の灰色周辺刺激が呈示さ れ，これがテスト刺激側の周辺刺激とは異なっているためである と考えられる。

\section{1 .3 モンドリアン周辺刺激}

困5(a), (b)，(c)，(d)にモンドリアン周辺刺激の全被験者の結 果を示す。apparent－color matchの色度座標( $\square$ シンボル)は図 4 の灰色周辺刺激の場合に比べて完全な色恒常性(○シンボル)成 立方向に近い結果が得られている。ここで, apparent-color matchの判断基準は図4と同じであることに注目すると, 周辺刺 激に色のバリエーションが加えられただけでさらに色恒常性に近 い結果が得られていることがわかる，表面色の知覚に関するマッ チングである surface-color matchの結果(ロシンボル)では, さ らに色恒常性に近いマッチング点が得られていることがわかる.

$1,000 \mathrm{~K}$ については灰色周辺刺激での結果と同様である.

surface-color matchの結果は被験者の見えがRAを除いて 完全に無彩色であることを示している. apparent-color match の結果はテスト刺激の色度点と surface-color match 結ぶ線 上のほぼ中間点にあり，周辺刺激を呈示することによって見えの 彩度が低下していることがわかる。

\section{2 順応条件}

順応条件での被験者 IK の結果を図6に示す. 図2 5 と同様に口 シンボルは apparent-color matchの結果を表し, 3,400K

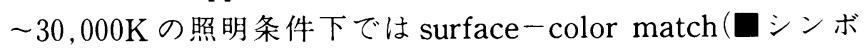
ル)とほぼ同等の色恒常性の成立を示している。すなわち, 順応時 のこれらの照明条件下では見えレべルで，ほとんど完全な色恒常 性が得られていることを示している，1,700K,2,400Kにおいて は, 3,400K $30,000 \mathrm{~K}$ の照明条件下とは異なり, apparent-color match と surface-color match との間に大きな隔たりがある.表 面色知覚レベルでの色恒常性は得られているが，見えのレベルで は明らかに色恒常性が失われていることを示している， $1,000 \mathrm{~K}$
については非順応条件と同様の結果が得られた。

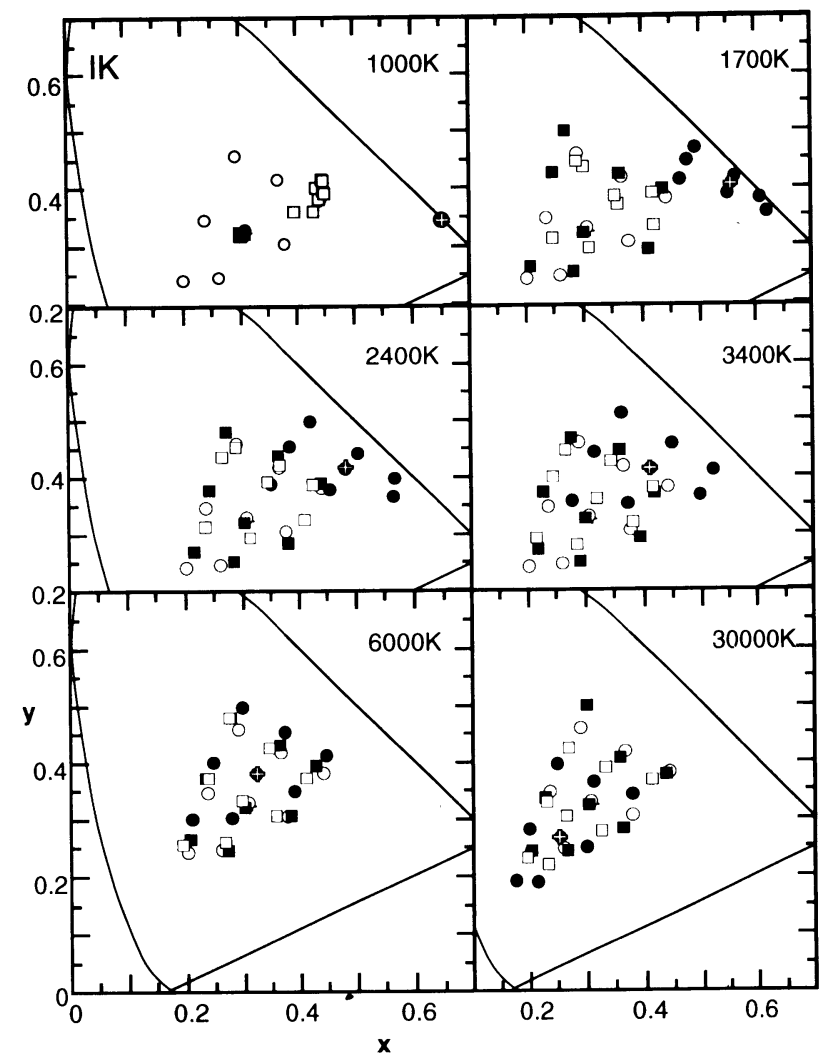

図 6 順応時, モンドリアン周辺刺激の被験者 IK の結果

シンボルは図4に同じ。ロシンボルがほぼロンボルに一致し, apparentcolorが順応によって surface-color とほぼ同等の高い色恒常性を示してい ることが分かる。

\section{4. 結果の解析}

\section{1 評価}

色恒常性の成立の度合いを調べるための結果の評価は次のよう に行なう。各テスト色票のマッチング結果に対して，その色度座 標と色恒常性が完全に成立した時の色度座標, すなわち $\mathrm{D}_{65}$ 照明 下における各テスト色票の色度点, の間の距離をu'v'空間上で計 算する.これは, 参照刺激における周辺刺激が $\mathrm{D}_{65}$ 照明下での色度 点を模擬しているためである.その計算結果を周辺刺激, 照明光, 判断基準別に平均し, その観察条件 (周辺刺激, 照明光, 判断基準) における色恒常性からの偏差とする。全てのテスト色票のマッチ ング結果が完全に色恒常性を示すときには, 色恒常性からの偏差 は0となる，以上を式に表すと次の通りになる。

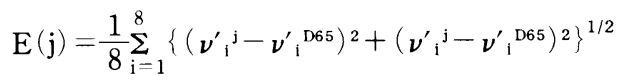

$\left(\boldsymbol{\nu}^{\prime}{ }^{{ }^{j}}, \boldsymbol{\nu}^{\prime}{ }^{\mathrm{j}}{ }^{\mathrm{j}}\right)$ はある観察条件(周辺刺激十判断基準+照明光) $\mathrm{j} に$

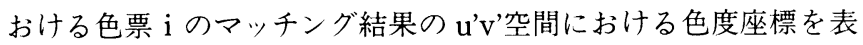
している。 $\left(\boldsymbol{\nu}^{\prime}{ }_{1}{ }^{\mathrm{D} 65}, \boldsymbol{\nu}^{\prime}{ }_{1}{ }^{\mathrm{D} 65}\right)$ は $\mathrm{D}_{65}$ 照明光下における色票 $\mathrm{i}$ の測色值 に基づく u’v'色度座標を示している，この評価式ではあくまで被 験者の色味の感覚を評価することを念頭においており, 輝度 (ある いは明度)の偏差は考慮にいれていない.この理由については考察 において詳しく述べる。 
全ての被験者の実験結果について式(1)に基づいて偏差評価を 行なった。図7 (a)〜 (d) は全ての被験者の1,700K〜30,000Kにお ける apparent-color matchの結果をプロットしたものである. パネルの違いは被験者の違いを表している。縦軸は (1) 式で定義し た偏差評価量である。縦軸の值が小さければ小さいほど色恒常性 の成立の度合いが高いことを示す．指標として照明光の変化によ るテスト刺激の測色点のシフトもプロットしており，この点に実 験結果の解析点が一致すると完全に色恒常性が失われていること を示すことになる，横軸は照明条件の違いを示しており，スケー ルは u’v'空間における各照明光の色度点の $\mathrm{D}_{65}$ 照明光の色度点か

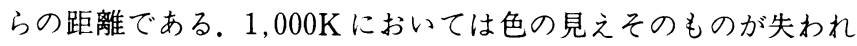
る形で色恒常性が完全に失われたため，色の見えがどのくらい完 全な色恒常性からずれているかという解析には $1,000 \mathrm{~K}$ の結果は 用いなかった。この偏差評価方法についてはのちに考察する.

非順応状態の実験では被験者は交互に開閉するタイマー制御シ ヤッターを通して右眼単眼で各々の刺激を観察する。シャッター の開閉時間は $\mathrm{D}_{65}$ 照明光の参照刺激側がテスト刺激側の1.5倍で あり，試行間にはブース内の $\mathrm{D}_{65}$ 照明に順応している.さらにテス 卜刺激の照明光は試行ごとにランダムに変えられることから，テ ス卜刺激側の特定の照明光への順応は最小限に押さ之られ，被験 者の視覚系は主として $\mathrm{D}_{65}$ 照明に順応していると考えられる.

図7のシンボルは, 周辺刺激条件と判断基準の違いを表してい る.周辺刺激なしの条件では物理的色シフトと全く重なっている

(a)

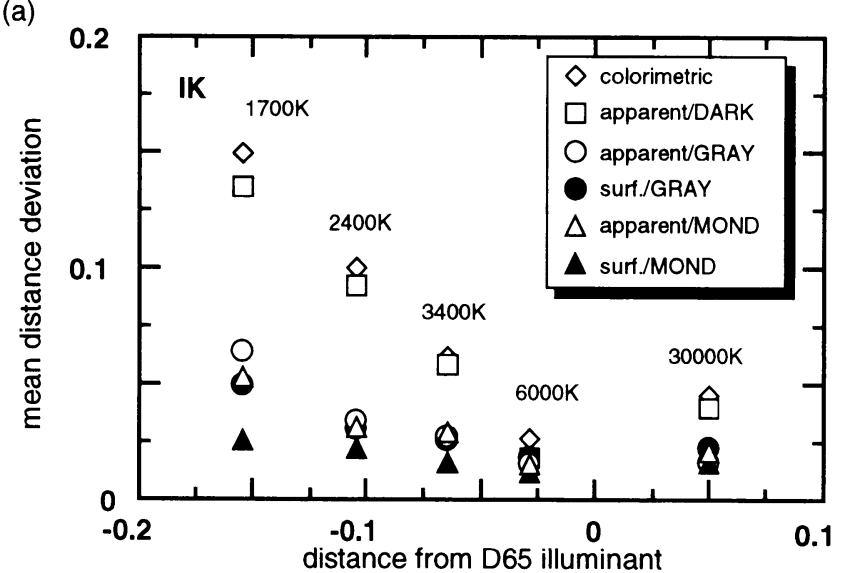

(c)

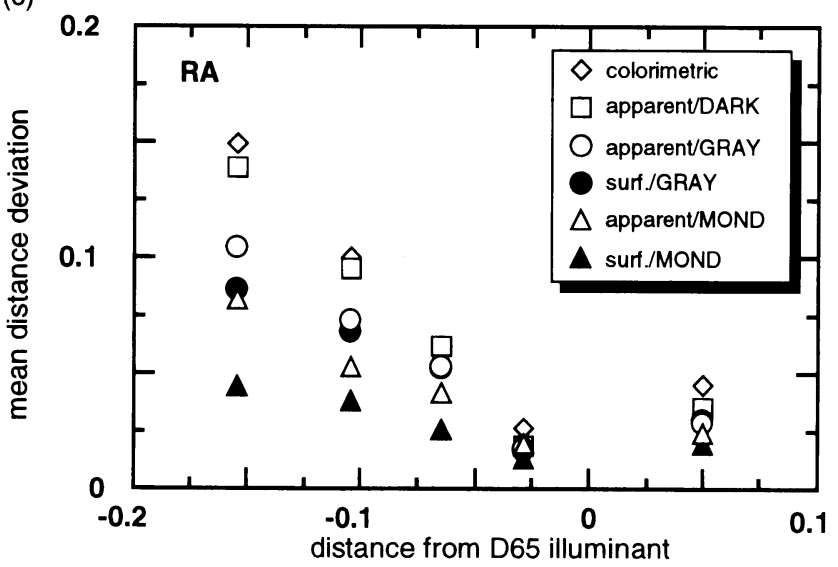

ことから，完全に色恒常性が失われていることを示している，灰 色周辺刺激の条件を示す点はテスト刺激側の各々の照明条件にお いてテスト刺激の測色点のシフトを示す点よりも下に位置し，比 較的良い色恒常性が得られていることを示している。モンドリア ン周辺刺激の結果では，いずれの被験者も灰色周辺刺激の surface-color match とほぼ同程度の色恒常性が得られていること を示しており，順応が行なわれていない条件下でも周辺刺激に色 の手掛かりが増えることで高い色恒常性が得られると言える.

図8において順応時と非順応時のモンドリアン周辺刺激の結果 とを比較すると, 順応時の方が高い色恒常性を示している。非順 応時には見之の知覚 (apparent-color match) が表面色知覚 (surface-color match)に一致しておらず，見えではテスト刺激，参 照刺激の間に部分的な色知覚の不一致があることを示している. 一方で順応時の apparent-color matchの結果はsurfacecolor matchの結果にほぼ一致していることから, 照明光への順 応によって apparent color と surface color とが共にほぼ完全な 色恒常性を得ていることがわかる.

\section{5. 考察}

\section{$5.12 つ$ 判断基準について}

本実験では,2つの異なる照明光の下にある刺激の色知覚を合わ せる実験(非対称マッチング)の判断基準として apparent-color match と surface-color matchの2種類を用いた. apparent-
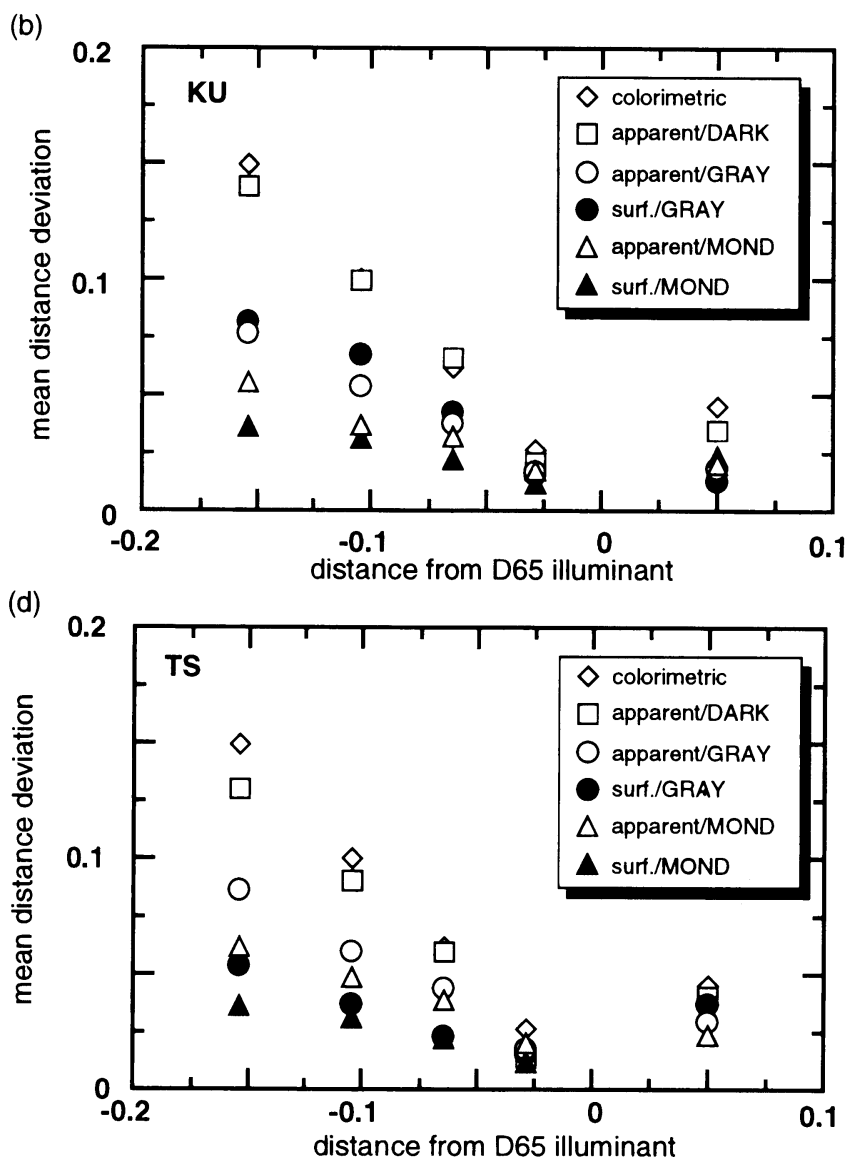

図 7 非順応時の色恒常性成立の度合いの評価

縦軸は式 (1)による色恒常性の成立の度合いを示す評価量で, 值が0の時に完全な色恒常性が成立していることを示す. 横軸は各照明光の色度点の $\mathrm{D}_{65}$ 照明光の色度点 からの距離を u'v'空間上でとったものを表している.パネルは被験者の違いを示し，シンボルの違いは判断基準と周辺刺激条件の違いを表している. ○シンボルはテ スト刺激の色度点を式(1)の評価量で表したもので，これに一致すると完全に色恒常性が失われていることを示す．凡例中の appear.は apparent一color match, surf.は surface-color match, DARKは周辺刺激なし, GRAYは灰色周辺刺激, MONDはモンドリアン周辺刺激を表している. 
(a)

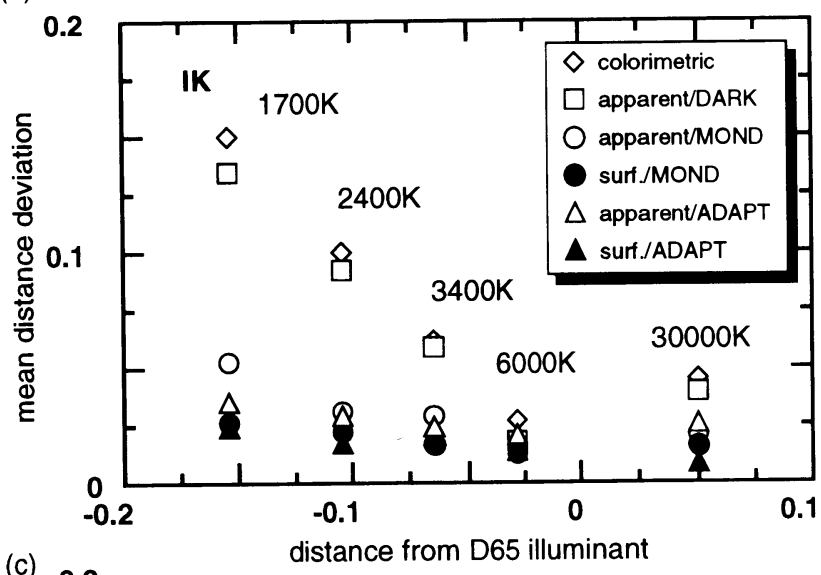

(c) 0.2

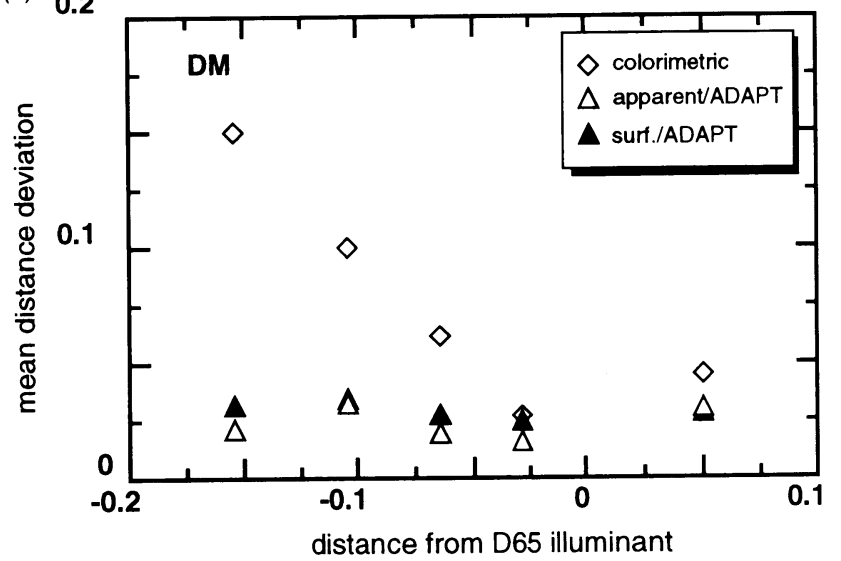

(b) 0.2

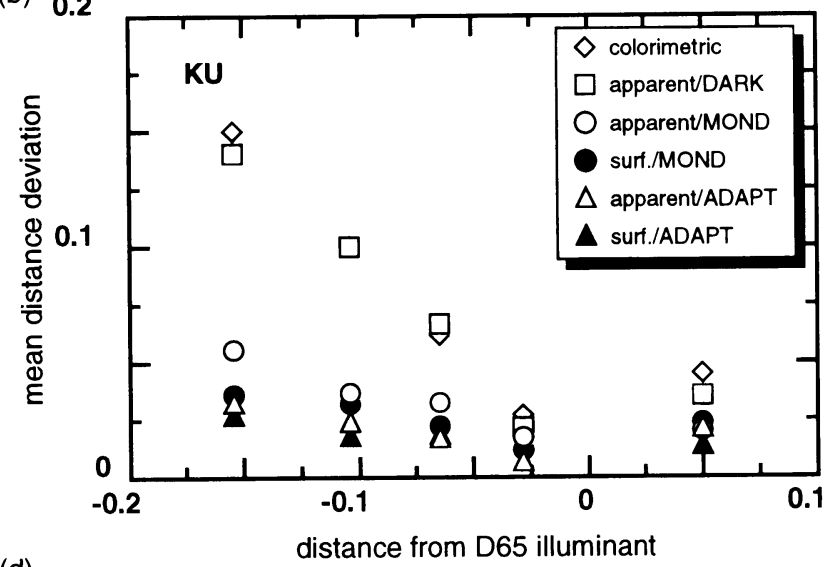

(d)

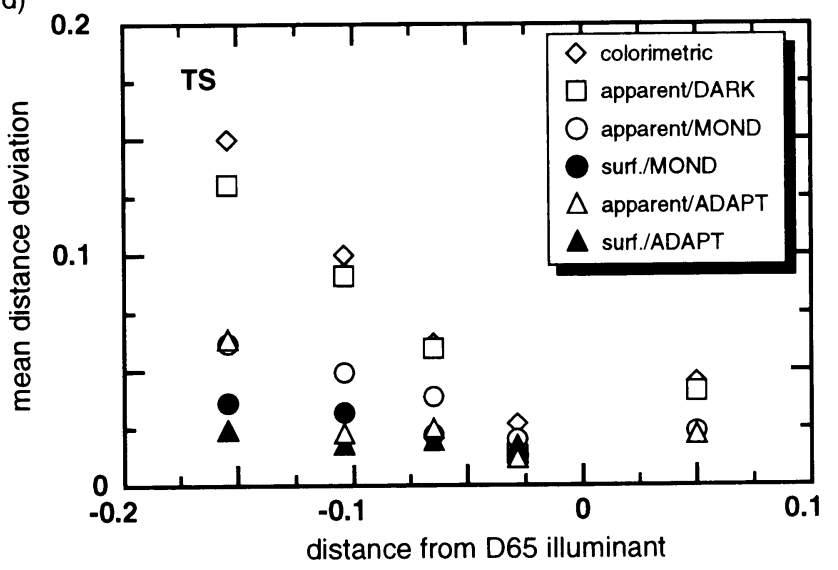

図 8 非順応時と順応時の色恒常性成立の度合いの比較

横軸，縦軸，ならびにつシンボルの意味は図7に同じ。凡例中の略語は図7のものに加え，ADAPT は順応時(モンドリアン周辺刺激のみ)を表している。

color match は見えの色を合わせる判断基準であり，マクスウエ ル視光学系の二分視野で行なわれているようなカラーマッチング の判断基準と同等と考えられる. surface-color match は見えそ のものの色よりも物体表面の属性としての色, すなわち表面とし ての色を合わせるマッチングで，表面色を用いた実験においての み考慮される判断基準である. 実験結果から, 全ての被験者がこ の二つの判断基準を使い分けられていることがわかる．そこで, surface-color match が apparent-color match と比較して知 賞としてどの程度安定しているかをみるために，それぞれの精度 をマッチング結果の試行間の標準偏差(s)を比較した。図9は非順 応時でモンドリアン周辺刺激の時の surface-color match と apparent-color matchの結果の試行間の標準偏差を，照明条件 別にxy 色度座標での大きさに換算したものである．今回は輝度 方向の検討は割愛したが, これについては後述する. 比較のため, 同じ評価を周辺刺激なしの apparent-color matchに対して行 ったものを黒いシンボルで表した.周辺刺激なしの刺激条件では， 被験者は両方の刺激の測色点が同じになるように合わせることに なるため, その標準偏差はいわゆる MacAdamの色弁別棈円に相 当したものになる。パネル $(\mathrm{a}) \sim(\mathrm{d})$ の違いは被験者の違いを表し ており, RA はナイーブな被験者である.結果は周辺刺激なしの時 の結果と比較すると, apparent, surface-color match ともに $6,000 \mathrm{~K}$ より離れるに従って大きくなる様子を示した。

apparent - , surface-color matchの間で比較すると, 両者と
も標準偏差の大きさはほぼ同じで，条件によっては apparent一 color match りりも surface-color matchの方が小さな值を示 している.ナイーブな被験者においても傾向は同じであり, 被験 者間で比較しても共通の知覚として安定して得られることが示さ れた. 以上から, surface-color match $と$ apparent-color match の2つの判断基準はほぼ同程度の安定性を持った知覚に基づいて いることが示された。

\section{2 色差による偏差評価方法について}

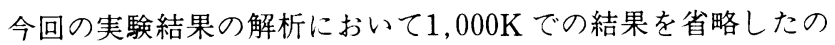
は, テスト刺激の色度点が参照刺激に用いた CRTの色再現範囲 を逸脱していることに加え, 色恒常性の程度を評価する方法が $1,000 \mathrm{~K}$ では適切でないと考えられるためである. 全ての色票が 無彩色の見えになると, この偏差評価量は $0.568 に 一$ 致することか ら，1,700Kの周辺刺激なしの apparent-color matchの結果よ りも無彩色の見えの方が色恒常性の程度がよいという結果になっ てしまう。しかしながら, 共に色恒常性が完全に失われている意 味においては同等であるため，この評価量が全く意味をなしてい ないことになる。これは偏差評価量として色度図上における距離 のみを用いているためであるといえる。本論文で採用した色差量 のみによる偏差評価は, 過去にも明るさや色の恒常性の成立の程 度を表す係数として試みられている ${ }^{910)}$.

今回の偏差評価量に限らず，一般に，各刺激の完全な色恒常性 
(a)

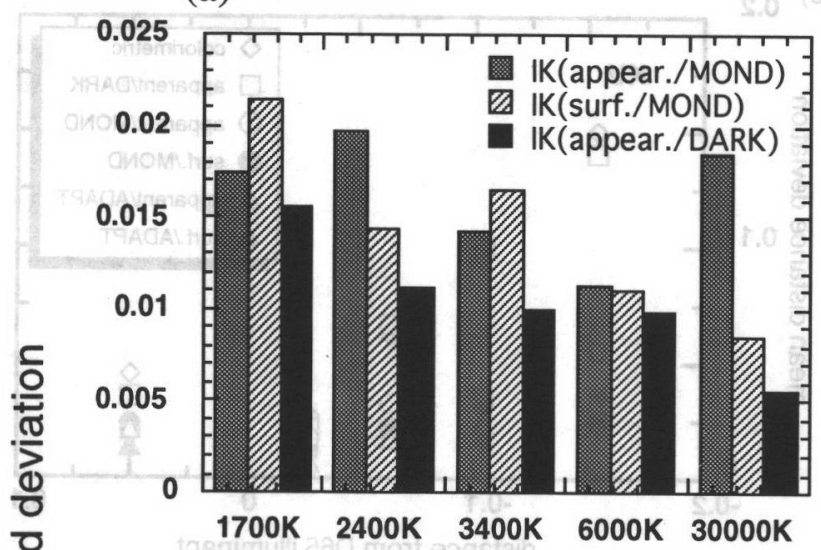

(c)

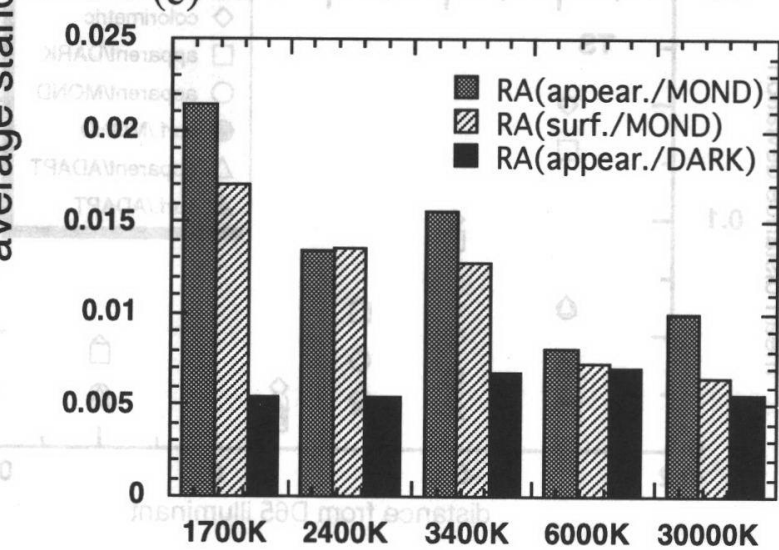

(b)

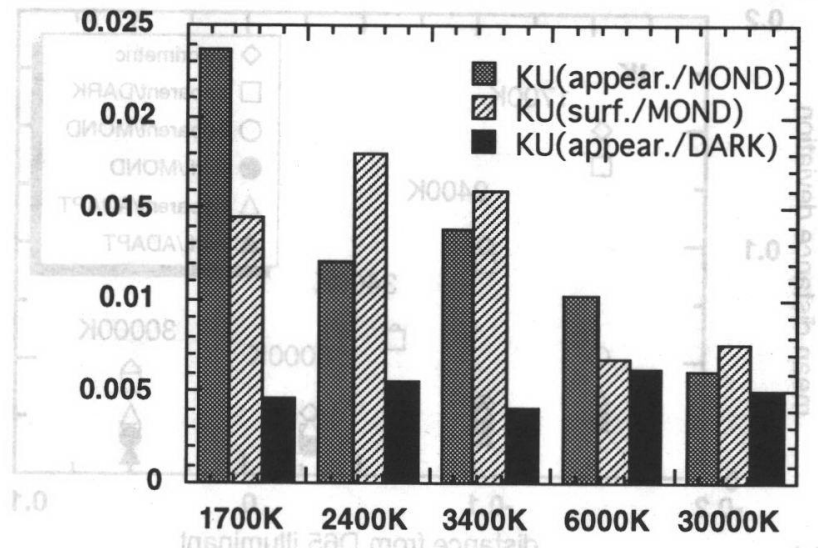

(d)

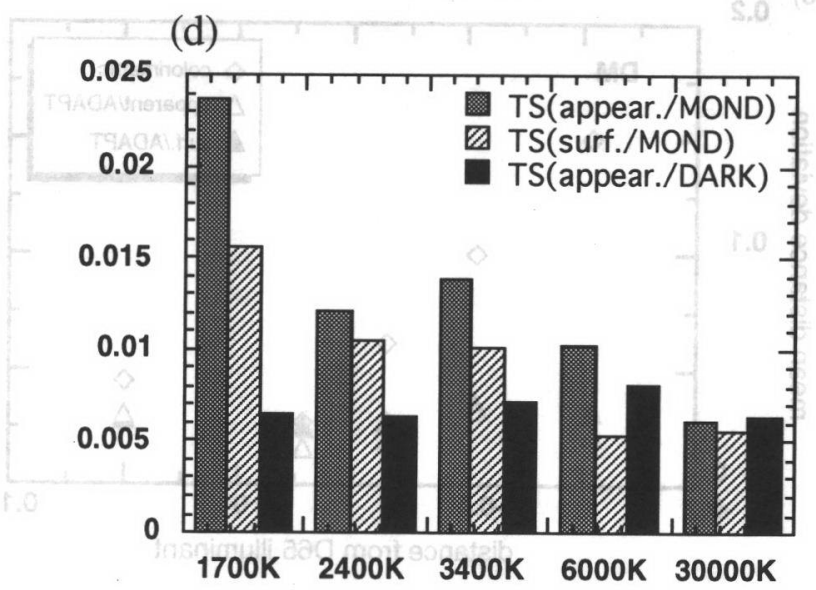

図 9 判断基準の違いの評価

横軸は照明光の違いを表し, 縦軸は一つの周辺条件, 判断基準及び照明条件でのマッチング結果の $\mathrm{x}$ 方向, $\mathrm{y}$ 方向の標準偏差( $\mathrm{s}$ )を全色票にわたって平均し，その二 乗和を解平したものである。パネルは被験者の違いを表している。凡例中の appear.は apparent-color matching, surf.は surface一color matching，MOND は 非順応時のモンドリアン周辺刺激，DARKは周辺刺激なしの条件を表している。 appear. DARKの結果は MacAdamの色弁別楕円に相当する。

成立時の色度点を原点とした色差による評価量は, 色相と彩度の 変化を区別することができないという欠点もある．しかし色相と 彩度の変化を何らかの方法で別々の評価量を設けて評価した場合 には，逆に色相と彩度の評価量をどのような重みづけで統合する かという問題も含むことになる。この評価方法の議論は重要なも のであるが, 本論文の主題から外れるために，ここでは色差量に よる偏差評価を色恒常性からのずれとして考えて差しつかえない 範囲の約 $1,700 \mathrm{~K}$ から $30,000 \mathrm{~K} に お け る$ 結果のみを用いた。ただ し今後の課題として, 色相と彩度といった次元を考慮した色恒常 性の評価量に関する検討が必要であろう。

\subsection{CRT と色票の間のカラーマッチングについて}

本実験では, テス卜刺激として OSA 均等色尺度の色票, 参照刺 激として CRT 上に呈示した疑似色票を用いた。色票を完全な暗 黒中で宙に浮くように支持し, 色票の脇を漏れた光すらも被験者 に見えないようにスポットライトを照射すると, 周辺刺激なしで は色票であっても発光体のような見え，すなわち開口色モードの 見えになる. 一方, CRT を完全な暗黒の中に置いて, テス卜色票 に周辺刺激をつけた状態を模擬した画面を呈示すると, 実際の色 票との区別がつけられなくなり，表面色モードの見えを得ること ができる1112)

しかし，本実験ではCRT で表示する画面では一部のテスト色
票の見えを再現できないことが生じた. 具体的にはくすんだ色， 若干の黒味がある色などの見えが再現ができなかった。実験では このような色票とのマッチングの際に被験者は実際のテスト刺激 の輝度よりも，輝度を下げることによって見えを合わせようと試 みている。つまり，色の見えは合っていても明るさが合わない状 態でマッチングを終了せざるをえない状況が存在した。これは， 被験者は輝度を合わせることよりも色の見えを合わせることを重 視してマッチングを行なったことの要因ともなっている、今回の 実験の解析において輝度方向の特性を省略したのは以上の理由か らである。この輝度方向の特性については, 次の節で詳しく説明 する.

物理的には CRT は自発光体, 色票は反射物体である.視覚系に 入射する光という意味では両者とも同じ物理量を持っていたとし ても，今回の実験のように，見えの違いを生ずることは CRT と印 刷物などの表示デバイス間の問題として広く知られていることで ある ${ }^{13)}$.この見えの違いの原因を究明するために, 各方面で積極的 に研究が行なわれているが, われわれも今回の実験と同じ実験装 置でカテゴリカルカラーネーミング，カテゴリー比率評価法によ って，CRT と色票の間での色の見えを比較した実験を行ってい る. その結果では, 表面色モードと開口色モードのいずれにおい ても, CRT と色票の間で色の見えにほとんど差がないことが示さ れている ${ }^{1112)}$. 今回の実験のテスト刺激のくすんだ色や黒味とい 
った見えは色票表面のテクスチャによって生じたもので, CRT 側 ではそれが再現できなかったために見えの違いが生じたとも考え られる。しかし，ここでは実験的な確認を行なうことはできなか った。

\section{4 輝度方向のマッチングの傾向について}

図10は非順応時の3人の被験者のマッチング結果とテスト刺激 の輝度比を色票, 照明光, 周辺刺激別にプロットしたものである. パネルの違いは周辺刺激の違いを表している，縦軸はマッチング 結果とテスト刺激の輝度の比の対数をとったものである．横軸は 8 枚の色票ごとに5種類の照明条件を表している. 左から, 色票 (一 $2,-2,0)$ に対する $1,700 \mathrm{~K}, 2,400 \mathrm{~K}, 3,400 \mathrm{~K}, 6,000 \mathrm{~K}, 30,000 \mathrm{~K}$, 色 票 $(-2,-2,2)$ に対する $1,700 \mathrm{~K}, 2,400 \mathrm{~K}, \cdots$ ，といj順番である. OSA 均等色尺度 $(\mathrm{L}, \mathrm{j}, \mathrm{g})$ の うち $\mathrm{L}$ は明度を表し, $\mathrm{j}$ は黄色み(負の 場合は青み), $\mathrm{g}$ は緑み(負の場合は赤み)を表している。( $\mathrm{L}, \mathrm{j}, \mathrm{g})=$ $(-2,0,0)$ はマンセルの N 5 に対応する.同じ被験者の, 同じ色票 に対する結果は線で結んであり, シンボルの違いは被験者の違い を表している.

apparent-color matchにおいては周辺刺激なしの条件では, 被験者間でマッチング結果とテスト刺激の輝度比に差はあるもの の，被験者内では $(-2,0,-2),(-2,2,-2) の 2 つ の$ 色票をのぞい てほぼ安定している。灰色周辺刺激, モンドリアン周辺刺激条件

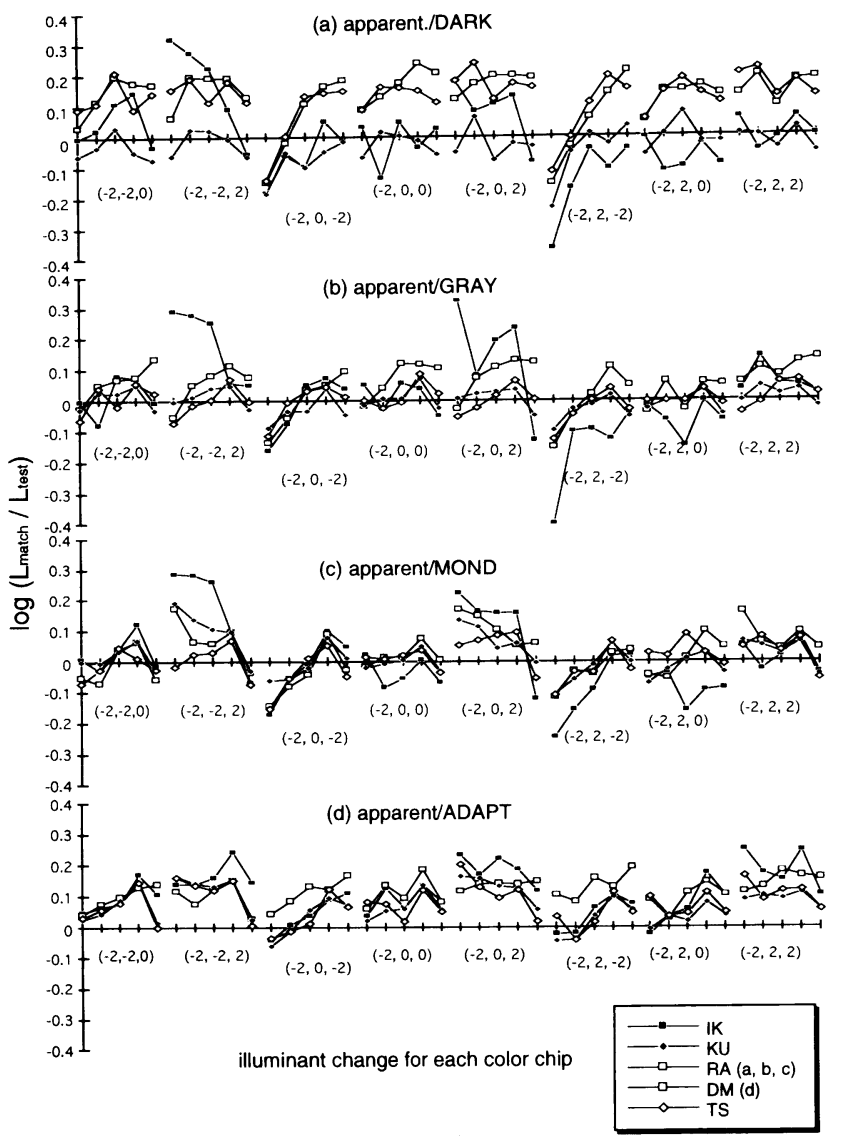

については,マッチングとテスト刺激の間の輝度比はほぼ1に等し く(縦軸の0に相当), 輝度が一致していることが分かった。色票 $(-$ $2,0,-2),(-2,2,-2)$ については, 灰色周辺刺激, モンドリアン 周辺刺激と周辺の情報が増えるに従って輝度比の照明光による差 が小さくなっている.

surface-color match に関しては灰色周辺刺激，モンドリアン 周辺刺激条件のいずれにおいても,ほぼ同様の傾向を示している. $(-2,0,-2),(-2,2,-2)$ のつの色票のに関しては照明光が約 $1,700 \mathrm{~K}, 2,400 \mathrm{~K}, 3,400 \mathrm{~K}$ において特に他の色票と異なって縦軸 の值が負になり，マッチングの輝度がテスト刺激の輝度より低い ことを示している。これは 5.3 節で述べたように，〈すんだ，ある いは黒味のある見えを再現するために輝度を低く設定しているこ とを表している。逆に $(-2,-2,2),(-2,0,2),(-2,2,2)$ の色票 に関しては, 照明光の色温度が低いほどマッチングの輝度がテス ト刺激の輝度より高いことを示している。

以上をまとめると, CRT と色票の間で行なうカラーマッチング では, apparent-color matchにおいてはどの色票についても輝 度がほぼ一致するが, surface-color matchにおいては一部の色 票では輝度が一致しない. 今回用いた色票および照明光の組み合 わせでは, 色温度が低いほど, 緑みのある色票は CRT の輝度を高 く，赤みのある色票に対しては輝度を低く合わせている傾向がみ られた。

\section{5 順応と周辺刺激の効果について}

本研究では瞬時色恒常性における周辺刺激の効果が, 色順応の ある条件と比較してどの程度高いかを評価するために，モンドリ アン刺激を周辺に呈示した上で15分間の予備順応を含んだ実験を

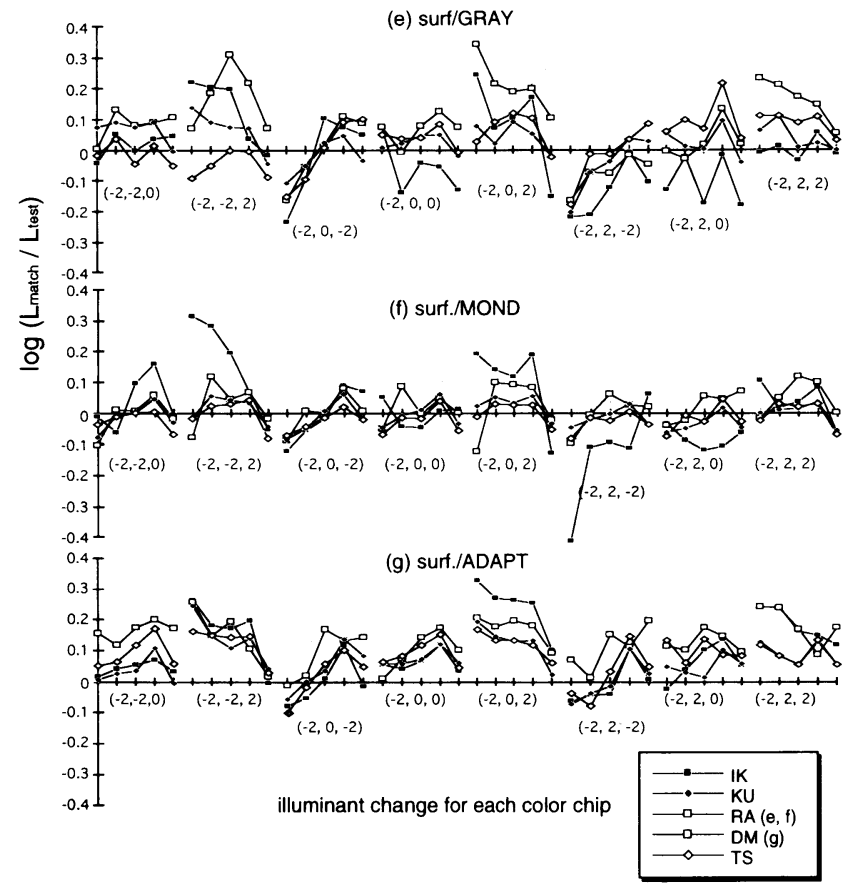

図10 輝度方向の偏差の評価

絴軸はマッチング結果とテスト刺激の輝度の対数を取ったものである.横軸は色票ごとの照明条件の違いを表している。パネル(a)〜(d)は apparent－colormatchの 結果, パネル (d) 〜 (f) は surface-color matchの結果を表している.シシンボルは被験者の違い, パネルは周辺条件および判断基準の違いを表している。同じ被験者 の同じ色票に対する結果は線で結ばれている。結ばれたシンボルは左から照明光が $1,700 \mathrm{~K}, 2,400 \mathrm{~K}, 3,400 \mathrm{~K}, 6,000 \mathrm{~K}, 30,000 \mathrm{~K}$ の時の結果を表している。被験者 $\mathrm{RA}$ は非順応条件(パネル $(\mathrm{a}) \sim(\mathrm{c}),(\mathrm{e}),(\mathrm{f}))$ のみ，被験者 DMは順応条件(パネル $(\mathrm{d}),(\mathrm{g}))$ のみを行った。 
行った.その結果, apparent-color match, surface-color match の順応時の結果はともに非順応時よりもさらに高い色恒常性を示 した. 特に apparent-color matchの結果と surface-color matchの差は非順応時よりも小さくなり, apparent color が surface color とほほ同等の色恒常性を示した.この傾向は順応時, 非順応時の両実験を行った全ての被験者において共通であり，非 順応時の色恒常性は周辺刺激における手掛かりを増やすことによ って向上するが, 完全な色恒常性を得るには至らず apparent color がほぼ完全な色恒常性を得るには順応が必要であることを 示している.

一方，周辺刺激なしの条件において，順応のみによって色恒常 性が成立することの可能性を検討してみる。本論文における周辺 刺激なしの条件の刺激配置のように，暗黒のなかにテスト／参照 の両刺激が単独で呈示された状態を仮定する，両刺激を素早く交 互に観察する条件 (非順応条件)では surface-color match が不 可能で, 色恒常性が完全に失われることは実験結果 (図3)から明ら かである。しかし，両刺激の測色点を同じに合わせることは可能 であった。

同様に周辺刺激なしの状態で，両眼隔壁を用い各々の刺激に左 右眼が別々に順応した状態でマッチングを行なうことを仮定す る。この刺激配置ではテスト／参照の各刺激を各々長時間観察す ることによって左右眼がそれぞれの視野の周辺刺激なしの刺激に 別々に順応する，言い換えれば，同じ紙を異なる照明で照らして 開口色モードの見えを生ずるときには，それぞれの眼に呈示され た刺激の色度点に視覚系は別々に順応する，順応によって色恒常 性が成立するためには，視覚系がそれぞれの刺激の照明光の色度 点の方向に順応する必要がある。しかし, 暗黒中に各眼に単一の 開口色モードの刺激を呈示すると視覚系は照明光の分光成分と表 面の分光反射率との積によって生じる色度点に順応する.従って, 各眼の順応状態は必ずしも各々の照明光の方向にシフトしない. 加之て, 周辺刺激がない場合, 空間的な情報の統合によってに順 応状態の違いを補正する手掛かりは与えられない。従って, 周辺 刺激抜きで順応のみによって必ずしも色恒常性を得ることはでき ない.

一方, Uchikawa ら ${ }^{14) 15)}$ は, 暗黑中に未知の照明光によって照明 された状態でテスト刺激を呈示しても, テスト色票に対して面積 比1 16の灰色の周辺刺激をつけることでカテゴリカルカラーネー ミングにおいて色恒常性が得られたと報告している。この実験は, 被験者の照明光に対する順応時間が不定であり，マッチング実験 でないことから我々の実験結果と直接の比較を行なうことはでき ないが，周辺刺激が色恒常性に寄与する効果が大きいことを示し ていると言えよう。

これらのことを総合すると, 瞬時色恒常性は周辺刺激の手掛か りの増加によって向上し, ある程度の高い色恒常性を得ることが できる．しかし，周辺手掛かりを増やしても照明光への順応なし では完全な色恒常性には至らない。一方で，順応のみによっても 完全な色恒常性を得ることはできないため, 周辺刺激の手掛かり と順応作用が総合されて初めて完全な色恒常性を得ることができ ると考えられる。

\section{6. おわりに}

以上の実験から導かれる結論をまとめると，以下のとおりにな る. 周辺刺激は apparent color における瞬時的色恒常性を向上さ せる.モンドリアン周辺刺激呈示時における apparent color は，
灰色周辺刺激呈示時の surface color にほぼ一致する程度の瞬時 的色恒常性を得ることができた.ただし, 非順応時には, apparent colorにおいて surface color と同等の色恒常性を得ることはで きず，照明光への順応を加えることによって初めて apparent color が surface color と同等の色恒常性を得られる事が明らか になった。

\section{参 考 文 献}

(1) I. Kuriki, and K. Uchikawa,:"Limitations of Simultaneous Color Constancy," (in preparation)

(2) H. von Helmholtz, :"Treatise on physiological optics, " 1st ed. [1866] (3d ed. reprint; J. P. C Southall, trans). New York: Dover (1962)

(3) M. D'Zmura, and P. Lennie,:"Mechanisms of Color Constancy," J.Opt. Soc. Am. A, 3, pp. 1662-1672 (1986)

(4) E. Land,: "Recent advantages in retinex theory," Vision Res., 26, pp.7-21(1986)

(5) J. von Kries, "Chromatic adaptation," Festschrift der Albrecht-Ludwigs-Universitat, (1902)

(6) D. H. Brainard, and B. A. Wandell,: "Asymmetric Color Matching," J. Opt. Soc. Am. A, 9, pp. 14331448 (1992)

(7) J. Walraven, T. L. Benzshawel, B. E. Rogowitz, and Lucassen, M.P.:"Testing the contrast explanation of color constancy, "From Pigments to Perception, (Valberg, A. and Lee, B.B. ed.), New York: Plenum Press, pp.369-377 (1991)

(8) A. Valberg, and Lang-B. Malecki, "'Color constancy' in mondrian patterns: a partial cancellation of physical chromaticity shifts by simultaneous contrast," Vision Res., 30, pp.371-380 (1990)

(9) L. Arend, and A. Reeves,: "Simultaneous Color Constancy," J. Opt. Soc. Am. A, 3, pp. 1743-1751(1986)

(10) E: Brunswik, "Zur Entwicklung der Albedowahrnehmung," Zeitschrift für Psychologie, 109, pp. 40115(1929)

(11) 内川惠二, 栗木一郎, 篠田博之：「開口色と表面色モード における色空間のカテゴリカル色名領域」, 照明学会誌, 77, pp. 346-354 (1993)

(12) 内川惠二, 栗木一郎, 篠田博之：「カテゴリ一比率評価法 による開口色と表面色モードの色の見えの表現」, 照明学会 誌, 78, pp. 83-93(1994)

(13) 鈴木恒男：「カラーアピアランスとカラーマネージメン ト：色の見えのモードを中心として」, VISION, 6, pp. $25-32(1994)$

(14) H. Uchikawa, , K. Uchikawa, and Boynton, R.: "Influence of achromatic surrounds on categorical perception of surface colors," Vision Res., 29, pp. 881-890 (1989)

(15) K. Uchikawa, ,H. Uchikawa, and R. Boynton,: "Partial color constancy of isolated surface colors examined by a color naming method," Perception, 18, pp.83-91 (1989)

（受付日1994年 7 月 13 日／採録日 1994年 9 月 8 日） 